\title{
Bryophyte communities and seston in a karst stream (Jankovac Stream, Papuk Nature Park, Croatia)
}

\author{
Maria Špoljar ${ }^{1 *} \uparrow$, Tvrtko Dražina ${ }^{1} \dagger$, Ana Ostojić ${ }^{1}$, Marko Miliša $^{1}$, Marija Gligora Udovič \\ and Dagmar Štafa ${ }^{1}$ \\ ${ }^{1}$ Division of Zoology, Department of Biology, Faculty of Science, University of Zagreb, Rooseveltov trg 6, HR-10 000 Zagreb, \\ Croatia \\ ${ }^{2}$ Division of Botany, Department of Biology, Faculty of Science, University of Zagreb, Rooseveltov trg 6, HR-10 000 Zagreb, Croatia
}

Received 7 February 2011; Accepted 22 September 2011

\begin{abstract}
An investigation into bryophyte communities in karst Jankovac Stream (Papuk Nature Park, Croatia) was carried out once a month from July 2008 to June 2009. Samples were taken from two lotic microhabitats: (i) Jankovac Spring (JS), a hypocrenal habitat with dense bryophyte clusters $(90 \%$ bottom cover) and (ii) Jankovac Waterfall (JW), with scattered bryophyte clusters (50\% bottom cover). At the same time, seston samples were collected during the spring as the source site and after the JW, as the outflow site. The goals of this study were to understand the (i) algal, protozoan and metazoan bryophyte community assemblages in these two lotic microhabitats, (ii) influence of environmental factors on the structuring of the bryophyte community and (iii) structure of seston along the longitudinal profile. A total of 172 taxa were determined: 68 algae, 55 protozoa, 24 meiofauna and 25 macroinvertebrates. Statistically significant differences between two microhabitats differing in percentage of bryophyte cover were established testing 13 environmental parameters. In dense bryophyte clusters, community structure was determined by flow velocity and $\mathrm{pH}$, and macroinvertebrates achieved higher diversity and abundance. On the contrary, in scattered bryophyte coverage algae, protozoa and meiofauna reached higher abundance and diversity governed by the amount of suspended organic matter and epiphyton. In contrast to previous studies, the inverse ratio of community diversity and abundance versus percentage of bryophyte cover was established. We assume this to be the result of an enrichment of the scattered bryophyte clusters by upstream seston. Additionally, the effects of anthropogenic hydromorphological disturbance are reflected in macroinvertebrate diversity and abundance reduction.
\end{abstract}

Key words: Flow velocity / algae / meiofauna / protozoa / macroinvertebrates

\section{Introduction}

Bryophytes prefer shallow, fast flowing water where they influence environmental factors by reducing flow velocity and increasing detritus sedimentation, as well as offering a refuge from predators and dislodgement stress (Suren, 1992; Miliša et al., 2006a). As plant hosts, bryophytes provide a valuable food source represented by an epiphytic algal community tightly attached to the cauloids and phylloids (Knapp and Lowe, 2009). Conveniently, light conditions, together with detritus deposition, ensure a broad range of food resources (algae, bacteria and detritus) and provide suitable areas for invertebrate colonization (Linhart et al., 2002). Thus,

\footnotetext{
*Corresponding author: mspoljar@zg.biol.pmf.hr

$\dagger$ Both authors contributed equally to this work.
}

bryophytic communities comprise a complex three-dimensional structure of microhabitats that are suitable for colonization by an array of algae, protists and invertebrates (Suren, 1991; Bowden et al., 2006).

Most investigations on aquatic bryophytes have dealt with macrofauna (Suren, 1991; Habdija et al., 2004; Miliša et al., 2006b), while protozoa and metazoan meiofauna (i.e., pass through a $500 \mu \mathrm{m}$ sieve, Fenchel, 1978) have been neglected. There are many studies on protozoa/ meiofauna in macrophyte stands (Sleight et al., 1992; Duggan, 2001; Bogut et al., 2010), but there are only few papers concerning these communities in bryophytes (Madaliński, 1961; Donner, 1972; Linhart et al., 2002). Recently, Reiss and Schmid-Araya (2008) showed the importance that protozoan's and meiofauna have in the diversity, abundance and functioning of food web 


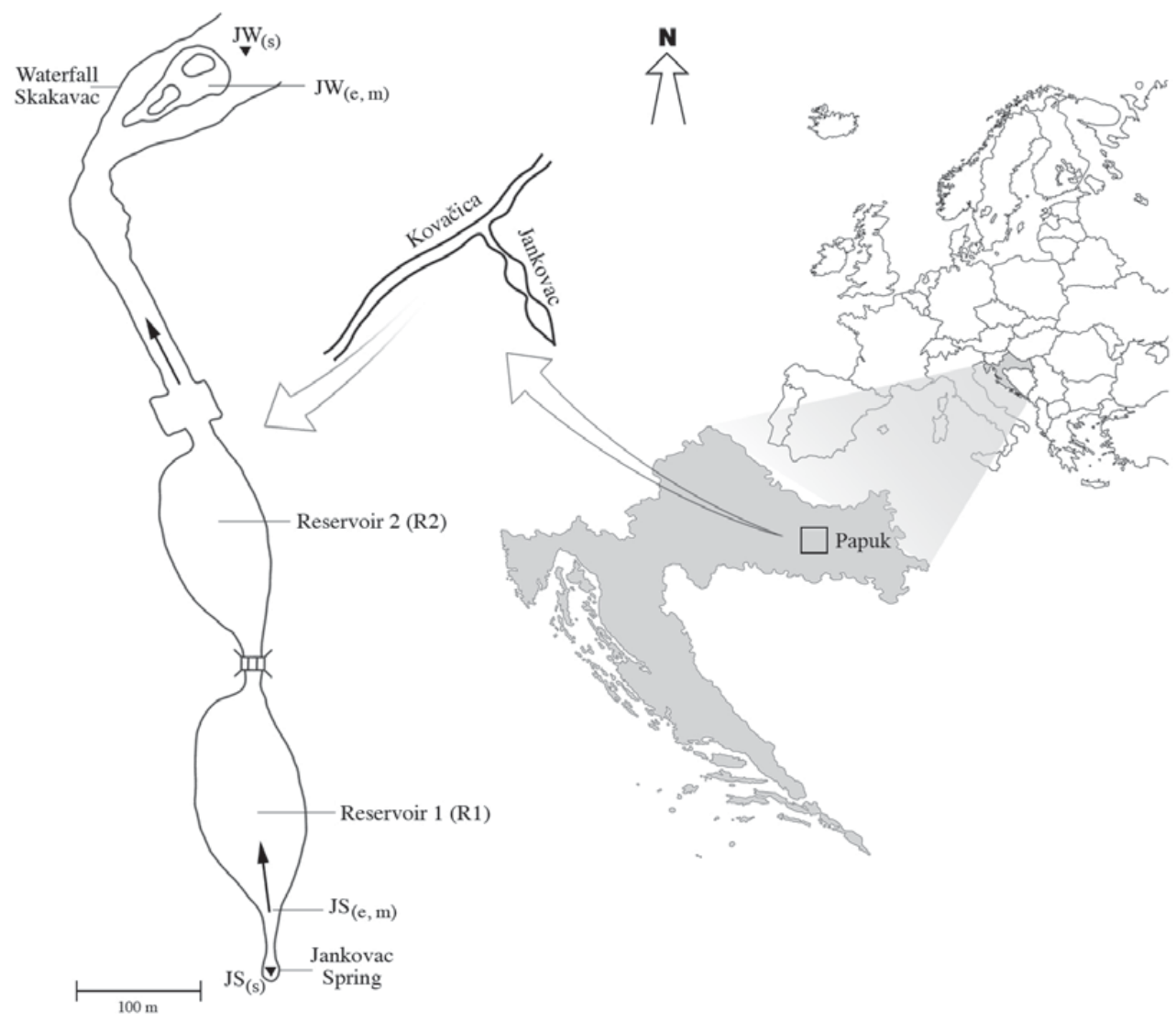

Fig. 1. Map of the Jankovac Stream (Papuk Nature Park) with marked sampling sites. JS $\mathrm{S}_{(\mathrm{s})}$, Jankovac Spring, sampling site for seston; $\mathrm{JS}_{(\mathrm{e}, \mathrm{m})}$, Jankovac Spring, sampling site for epiphyton and macroinvertebrates; JW $\mathrm{JW}_{(\mathrm{s})}$, Jankovac Waterfall, sampling site for seston; $\mathrm{JW}_{(\mathrm{e}, \mathrm{m})}$, Jankovac Waterfall, sampling site for epiphyton and macroinvertebrates.

dynamics of the whole benthic community through matter cycling and energy transfer. Therefore, these communities, as consumers of detritus, bacteria and periphyton, should be included in investigations of freshwater benthos to obtain a better insight into the functioning of freshwater ecosystems (Hakenkamp and Morin, 2000).

The second objective of this study refers to organic and inorganic particles in the current of running water of both autochthonous and allochthonous origins, dead or alive, i.e., seston (Breitig and von Tümpling, 1982). Seston originates from upstream stretches or drifts from stream beds in lotic stretches and thus comprises planktonic and benthic organisms (Sandlund, 1982; Špoljar et al., 2007a, 2007b). Its major role reflects in downstream food transport and organisms longitudinal dispersion (Descy et al., 2003; Sertić Perić et al., 2011).

Investigations of bryophitic communities are scarce; this study was undertaken to complete an all taxa biotic survey (ATBS) of algae, protozoa and meiofauna, as well as macrozoobenthos assemblages in a bryophyte community. Our goal was to compare seston assemblages at the source site and the outflow site situated at the mouth of the stream. We assumed that biocoenotic assemblage in bryophyte communities could be related to hydromorphological features of the stretch and food availabilities. Thereby, the main goals of this study were to establish: (i) algal, protozoan and metazoan bryophyte community assemblages in two lotic microhabitats with different percentage of bryophyte cover; (ii) the influence of environmental factors on the structuring of bryophyte communities; and (iii) structure of seston at the source and the outflow site of the stream. Results of our study will contribute to insight into biocoenoses of lotic, bryophyte habitats in karst waters and ecological determinants of their assemblage.

\section{Study area}

This investigation was conducted in Jankovac Stream (Papuk Nature Park, Croatia), situated on sedimentary carbonate rocks. Jankovac is a small, approximately $700 \mathrm{~m}$ long, first-order stream $\left(45^{\circ} 31^{\prime} 07^{\prime \prime} \mathrm{N}, 17^{\circ} 41^{\prime} 11^{\prime \prime E}\right.$; $475 \mathrm{~m}$ a.s.1.), consisting of a rheocrenous spring, two manmade reservoirs and the Skakavac waterfall with a recent tufa deposition (Fig. 1). The sampling sites for the epiphyton (e) and the macrozoobenthos (m) were situated in two lotic stretches (Tab. 1). First lotic stretch was hypocrenal part of the Jankovac Spring (JS), sampling site $\mathrm{JS}_{(\mathrm{e}, \mathrm{m})}$ (length $61 \mathrm{~m}$, mean width $3 \mathrm{~m}$, slope $3.8^{\circ}$ ), surrounded by deciduous forest. The stream bed is covered with cobbles, pebbles and dense clusters of bryophyte cover (Tab. 1). After the hypocrenal stretch there are two shallow reservoirs, with well developed submerged 
Table 1. Sampling methodology and analysis at the sampling sites JS and JW on Jankovac Stream, Papuk Nature Park.

\begin{tabular}{|c|c|c|c|}
\hline & \multicolumn{3}{|c|}{ Sampling methodology and analysis } \\
\hline & Seston & $\begin{array}{l}\text { Epiphyton } \\
\end{array}$ & Macrozoobenthos \\
\hline$\overline{\mathrm{JS}}$ & $\begin{array}{l}\text { Small pool }\left(z_{\text {mean }} 0.15 \mathrm{~m}\right) \text { without } \\
\text { bryophytes in eucrenal part }\end{array}$ & $\begin{array}{l}\text { Dense clusters of bryophytes, } \\
90 \% \text { bottom covered }\end{array}$ & \\
\hline JW & $\begin{array}{l}\text { Small pool }\left(z_{\text {mean }} 0.5 \mathrm{~m}\right) \text { without } \\
\text { bryophytes after waterfall }\end{array}$ & $\begin{array}{l}\text { Scattered clusters of bryophytes, } \\
50 \% \text { bottom covered }\end{array}$ & \\
\hline Sampling & $\begin{array}{l}50 \mathrm{~L} \text { water filtered through the } \\
\text { plankton net } 26 \mu \mathrm{m}\end{array}$ & Corer ø $4 \mathrm{~cm}$ & Surber sampler $(25 \times 25 \mathrm{~cm})$ \\
\hline $\begin{array}{l}\text { Number of } \\
\text { samples }\end{array}$ & $\begin{array}{l}9 \text { months } \times 2 \text { sites } \times 3 \text { replicates } \\
=54 \text { samples }\end{array}$ & & \\
\hline Conservation & $4 \%$ formaldehyde & $\begin{array}{l}\text { Zooepiphyton: live material; } \\
\text { Phytoepiphyton: } 4 \% \text { formaldehyde }\end{array}$ & $70 \%$ ethanol \\
\hline Counting & $\begin{array}{l}\text { Petri dish; entire sample; inverted } \\
\text { microscope (Opton-Axiovert 35), } 100 \times\end{array}$ & $\begin{array}{l}\text { Phytoepiphyton: Stilinović and } \\
\text { Plenković-Moraj (1995); Zooepiphyton: } \\
\text { samples after multiple rinsing was } \\
\text { counted }(3 \times 1 \mathrm{~mL}) \text {; inverted } \\
\text { microscope, (Opton-Axiovert } 35), 100 \times\end{array}$ & $\begin{array}{l}\text { Petri dish; entire sample; } \\
\text { Stereomicroscope } \\
\text { (Zeiss Stemi 2000-C), } 50 \times\end{array}$ \\
\hline
\end{tabular}

vegetation and a maximum depth of approximately $2 \mathrm{~m}$

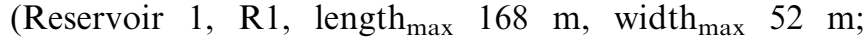
Reservoir 2, R2, length ${ }_{\max } 130 \mathrm{~m}$, width max $_{\max } 51 \mathrm{~m}$ ). The outlet of the second reservoir is partially channelled and leads to Skakavac Waterfall (height $32 \mathrm{~m}$, slope 63.4 ), and sampling site $\mathrm{JW}_{(\mathrm{e}, \mathrm{m})}$. The stream bed at the Skakavac Waterfall (JW) consists of boulders, tufa and scattered clusters of bryophytes (Tab. 1). The mosses in both lotic stretches were of Cratoneuron and Eurhynchium genera. For seston (s) sampling, source site $\mathrm{JS}_{(\mathrm{s})}$, was shifted upstream with respect to epiphyton and macrozoobenthos sampling, and was situated in the small pool within the cave immediately after arising, to investigate spring seston before drift influence over lotic hypocrenal stretch. Seston outflow sampling site $\mathrm{JW}_{(\mathrm{s})}$, was situated downstream in the small pool after the waterfall and over the tufa barrier, to analyse influence of lentic and lotic upstream stretches on seston assemblage (Fig. 1, Tab. 1).

\section{Materials and methods}

Sampling was carried out once a month from July 2008 to June 2009, except for November 2008 and January and March 2009 when the road to Jankovac Stream was obstructed by snow-cover or heavy torrents. Sampling locations were selected correspondingly to the ratio of microhabitats at each lotic stretch. The sampling methodology and biocoenotic analyses of epiphyton, macrozoobenthos and seston $(9$ months $\times 2$ sites $\times 3$ replicates $=54$ samples) are shown in Table 1 . Within each microhabitat replicate samples were taken randomly. Additional two seston samples were collected in the middle, i.e., mainstream of each reservoir, sampling points R1 and R2. In the text we consider seasonality as summer, SU (July, August), autumn, A (September, October), winter, W (December, February) and spring, SP (April, May, June).

Epiphyton samples were collected with a brass corer $(\emptyset$ $4 \mathrm{~cm})$ that cut through moss and adjacent sediment/tufa.
Samples were washed with water through two sieves (1 $\mathrm{mm}$ and retained on a $30 \mu \mathrm{m}$ mesh) to remove meiofauna from moss and mineral substrate (Linhart et al., 2002). First, we enumerated the live zooepiphyton $(100 \times)$ within $24 \mathrm{~h}$ of sampling, and then the sample was transferred to a bottle and fixed in $4 \%$ formalin. The phytoepiphyton density was estimated by counting three subsamples of $0.05 \mathrm{~mL}^{3}$ each on a millimetre grid with an area of $1 \mathrm{~cm}^{2}$ (Stilinović and Plenković-Moraj, 1995). Seston samples were collected by filtering $50 \mathrm{~L}$ of water through the plankton net (26 $\mu \mathrm{m}$ mesh), fixed in $4 \%$ formalin and the entire sample was counted in Petri dish under inverted microscope (Tab. 1).

Algal species were identified using the monographs of Zabelina et al. (1951), Patrick and Reimer (1966, 1975), Krammer and Lange-Bertalot (1986, 1991), Komárek and Anagnostidis (1999), John et al. (2002), and Komárek and Anagnostidis (2005). Protozoa (Sarcodina and Ciliophora) were identified to the genus or species level according to Ogden and Hedley (1980), Page and Siemensma (1991) and Foissner and Berger (1996). We use the traditional term Sarcodina, which includes naked and testate amoebae and heliozoans, although this term is not valid in the modern taxonomy of Protozoa (Adl et al., 2005). Rotifers were identified to the genus or species level according to Koste (1978). Bdelloidea were counted, but not identified. Cladocera and Copepoda were identified to the genus or species level using Margaritora (1983) and Einsle (1993).

Benthic macroinvertebrates were sampled using a $25 \times 25 \mathrm{~cm}$ Surber sampler (300 $\mu \mathrm{m}$ mesh). Specimens were identified based on Radoman (1983) and Glöer (2002) for Gastropoda, Waringer and Graf (1997) for Trichoptera, Zwick (2004) for Plecoptera, Bauernfeind and Humpesch (2001) for Ephemeroptera, Nilsson (1996) for Coleoptera and Nilsson (1997) for Diptera. Only taxa that amounted to more than $1 \%$ of the total catch at both sites were analysed.

Nematoda, Ostracoda, Hydrachnidia, Oligochaeta and Collembola were not identified. Gastrotricha, Copepoda, 
Table 2. Environmental parameters (means $\pm \mathrm{SD}$ ) in two sampling sites, JS and JW (Mann-Whitney $U$ test, $N_{\mathrm{JS}}, \mathrm{JW}=9$ ).

\begin{tabular}{|c|c|c|c|c|}
\hline & JS & JW & $Z$ & $P$ \\
\hline $\mathrm{T}\left({ }^{\circ} \mathrm{C}\right)$ & $10.59 \pm 1.94$ & $13.91 \pm 5.30$ & -1.5019 & 0.1331 \\
\hline $\mathrm{O}_{2}\left(\mathrm{mg} \cdot \mathrm{L}^{-1}\right)$ & $13.57 \pm 3.77$ & $12.14 \pm 4.46$ & 0.8830 & 0.3772 \\
\hline Conductivity $\left(\mu \mathrm{S} . \mathrm{cm}^{-1}\right)$ & $508.50 \pm 12.93$ & $428.78 \pm 26.41$ & 3.5321 & 0.0004 \\
\hline $\mathrm{pH}$ & $7.44 \pm 0.10$ & $8.16 \pm 0.40$ & -2.7388 & 0.0062 \\
\hline $\mathrm{CO}_{2}\left(\mathrm{mg} \cdot \mathrm{L}^{-1}\right)$ & $15.20 \pm 5.95$ & $4.11 \pm 2.44$ & 3.3712 & 0.0007 \\
\hline Alkalinity $\left(\mathrm{mg} \cdot \mathrm{CaCO}_{3} \cdot \mathrm{L}^{-1}\right)$ & $263.03 \pm 7.12$ & $230.00 \pm 16.54$ & 3.4527 & 0.0006 \\
\hline $\mathrm{N}-\mathrm{NO}^{3-}\left(\mathrm{mg} \cdot \mathrm{L}^{-1}\right)$ & $1.61 \pm 0.35$ & $1.08 \pm 0.52$ & 2.8286 & 0.0047 \\
\hline $\mathrm{P}-\mathrm{PO}_{4}^{3-}\left(\mathrm{mg} \cdot \mathrm{L}^{-1}\right)$ & $0.03 \pm 0.02$ & $0.31 \pm 0.38$ & -2.2982 & 0.0215 \\
\hline Flow velocity $\left(\mathrm{m} . \mathrm{s}^{-1}\right)$ & $0.47 \pm 0.30$ & $0.90 \pm 0.33$ & -2.4737 & 0.0134 \\
\hline Chl $a\left(\mu \mathrm{g} . \mathrm{L}^{-1}\right)$ & $0.11 \pm 0.12$ & $2.68 \pm 3.81$ & -3.1954 & 0.0014 \\
\hline AFDMs $\left(\times 10^{3} \mathrm{mg} \cdot \mathrm{L}^{-1}\right)$ & $0.41 \pm 0.14$ & $0.94 \pm 0.43$ & -2.9140 & 0.0036 \\
\hline $\operatorname{AFDMe}\left(\times 10^{3} \mathrm{mg}^{-\mathrm{cm}^{-2}}\right)$ & $0.08 \pm 0.03$ & $0.07 \pm 0.12$ & 2.4296 & 0.0151 \\
\hline $\mathrm{DMb}\left(\mathrm{g} \cdot \mathrm{cm}^{-2}\right)$ & $0.30 \pm 0.24$ & $0.25 \pm 0.13$ & 0.9428 & 0.3458 \\
\hline
\end{tabular}

Cladocera, Ostracoda Tardigrada and Hydrachnidia were pooled in a heterogenic group of organisms (called Others) within the seston and epiphyton assemblages, because of their low abundance.

In the field, standard instruments were employed to determine water temperature and dissolved oxygen concentrations (OXI 96, WTW GmbH, Weilheim, Germany), pH (pH 330i WTW GmbH, Weilheim, Germany), conductivity (sensION5, HACH, Loveland, CO, USA) and flow velocity (P600, DOSTMANN electronic, $\mathrm{GmbH}$, Wertheim-Reicholzheim, Germany).

Chemical parameters and phytoseston/algae biomass (chlorophyll $a, \mathrm{Chl} a$ ) were determined by analysing $3 \mathrm{~L}$ of non-filtered water $(9$ months $\times 2$ sites $\times 1$ sample $=18$ samples) (APHA, 1985; Höll, 1986, review Špoljar et al., 2011). Phytoseston and particulate organic matter in seston and epiphyton were considered as food resources for the main groups of investigated organisms. Chl $a$ concentration was determined using an ethanol extraction method (Nusch, 1980). To determine particulate organic matter in seston (ash-free dry mass (AFDM), 9 months $\times 2$ sites $\times 1$ sample $=18$ samples), additional $3 \mathrm{~L}$ of water was first filtered (Schleicher and Schuell White Ribbon 589/2, ashless quantitative filter paper) and then dried at $104{ }^{\circ} \mathrm{C}$ before being ashed $\left(600^{\circ} \mathrm{C}\right.$ for $\left.6 \mathrm{~h}\right)$. For epiphyton organic matter (ash free dry mass in epiphyton, AFDMe) corer samples were collected (9 months $\times 2$ sites $\times 3$ replicates $=54$ samples) and processed according to the washing procedure used by Linhart et al. (2002), larger macroinvertebrates were separated and thereafter samples were dried and ashed. We removed inorganic matter from bryophytes clusters and the remaining material was dried (bryophyte dry mass, DMb) and considered as the indicator of the cluster size.

Species richness $(\mathrm{S})$ was expressed as maximum taxa number in collected samples per site and date and these data were used in calculating similarity between two sites by Sørensen Index (SI) (Sørensen, 1948). In further analyses, the mean of triplicate samples was used as a single data point for a given date and site. Interactions between environmental parameters, food resources and epiphyton (algae, protozoa, meiofauna), seston and macroinvertebrates were analysed. Prior to statistical analysis, all abiotic and biotic data were transformed $[\log (x+1)]$; because they did not follow a normal distribution (Shapiro-Wilk's test) non-parametric analyses were used. These were as follows: Spearman correlations, Mann-Whitney $U$ test (comparison between two independent samples for spatial distribution of environmental parameters and biotic components) and Kruskal-Wallis test (comparison between multiple independent samples for seasonal distribution of environmental parameters and biotic components), as well as accompanying post hoc multiple comparisons were carried out using Statistica 9.1 (Statsoft, Inc. 2010). A nonparametric ordination (Nonmetric Multi-Dimensional Scaling, NMDS) was performed using the Bray Curtis similarity index computed through the organism's abundance data. We derived biota-environment matching for selected environmental variables best explaining community pattern using the multivariate analytical package PRIMER v6 (Clarke and Gorley, 2006).

\section{Results}

\section{Environmental parameters}

The sites differed significantly with respect to most of the environmental parameters, except for temperature and oxygen concentration (Tab. 2). pH, orthophosphate concentrations, Chl $a$, AFDMs content and flow velocity were significantly higher at the waterfall site (JW). On the other hand, conductivity, $\mathrm{CO}_{2}$ content, alkalinity and nitrate concentrations were higher at the spring site (JS). AFDMe was significantly higher in dense bryophyte clusters at JS, compared with the scattered bryophyte clusters at JW. No spatially or seasonally significant difference was observed for the DMb. Significant seasonal differences were exhibited only for temperature (KruskalWallis test, $H(3, N=18)=10.9, P=0.012)$ and dissolved oxygen (Kruskal-Wallis test, $H(3, \quad N=18)=10.4$, $P=0.020)$. As expected, according to multiple comparison, temperature was significantly lower during the winter $\left(7.8 \pm 1.9^{\circ} \mathrm{C}\right)$ contrary to the summer $\left(16.5 \pm 4.02^{\circ} \mathrm{C}\right)$ and fluctuated between 8 and $13{ }^{\circ} \mathrm{C}$ during the rest of the year. On the contrary, dissolved oxygen was significantly higher 

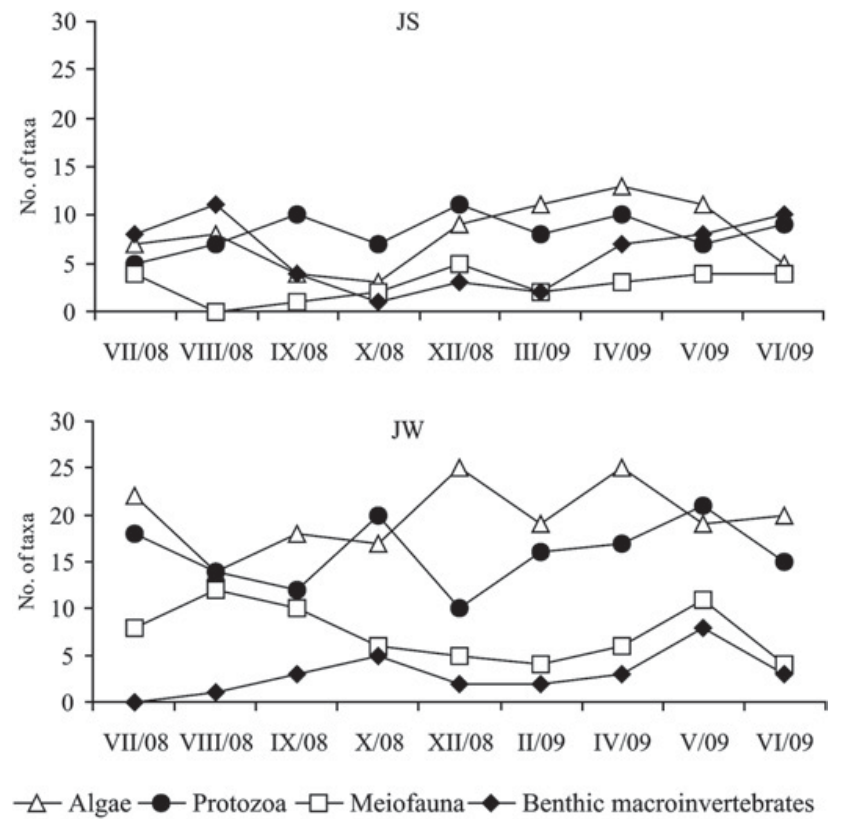

Fig. 2. Seasonal changes of species richness for investigated groups of organisms in dense (JW) and scattered (JS) bryophyte clusters. Roman numerals mark months and joined Arabic numbers mark year of sampling.

through the winter $\left(19.3 \pm 2.0 \mathrm{mg} \mathrm{O}_{2} . \mathrm{L}^{-1}\right)$ versus summer $\left(10.6 \pm 2.6 \mathrm{mg} \mathrm{O}_{2} . \mathrm{L}^{-1}\right)$ and spring $\left(10.4 \pm 1.9 \mathrm{mg} . \mathrm{L}^{-1}\right)$.

\section{Algal assemblages in the epiphyton and seston}

A total of 68 algal taxa were identified in the epiphyton samples of the Jankovac Stream, belonging to the Cyanobacteria (8), Euglenophyta (6), Chrysophyta (45) including most diverse Bacillariophyceae and Chlorophyta (9) (Appendix 1 available online). The maximum species richness (S) for algae was observed at both sites in spring (Fig. 2). In general, for phytophyton the Sørensen similarity index (SI) between the sites was averaged $26 \%$.

Results of the Mann-Whitney $U$ test showed significantly higher abundance of Cyanobacteria, Bacillariophyceae, Chlorophyta, as well as the total algal abundance at the JW, contrary to the JS (Tab. 3a). In the JS algal abundance in the epiphyton ranged from $0.5 \times 10^{5}$ to $14 \times 10^{5}$ cells.cm ${ }^{-2}$, with a prevalence of Bacillariophyceae $\left(2 \times 10^{5} \pm 1.6 \times 10^{5}\right.$ cells.cm $\left.{ }^{-2}\right)$. In the epiphyton at the JS first to peak was Diatoma mesodon $\left(1.7 \times 10^{5}\right.$ cells.cm $\left.{ }^{-2}\right)$, at the end of February. Thereafter, Cocconeis placentula reached maximum in April $\left(1.5 \times 10^{5}\right.$ cells.cm ${ }^{-2}$ ) and dominated in abundance at the JS (Tab. 3a). At the Jankovac Waterfall (JW) algal abun-

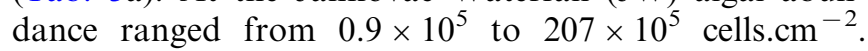
The epiphyton was significantly dominated by Bacillariophyceae species from the genus Achnanthidium, mostly comprised Achnanthidium minutisima and Achnanthidium microcephala, ranging between $0.6 \times 10^{5}$ and $27 \times 10^{5}$ cells.cm ${ }^{-2}$, with the April peak. In addition,
Fragilaria capucina (Bacillariophyceae) and cyanobacterial genus Phormidium also dominated in April and reached peaks of $42 \times 10^{5}$ and $37.5 \times 10^{5}$ cells.cm ${ }^{-2}$, respectively.

A total of 58 algal taxa were identified from the seston samples, with a pronounced domination of Bacillariophyceae (34 taxa) (Appendix 2 available online). Of these, 24 taxa were not found in the epiphyton. At the JS, the S was low (1-5 taxa), whereas at the JW increased (9-18 taxa). This resulted in a very low SI $(6 \%)$ between the investigated sites. The huge differences in algal abundances between JS (13-592 cells. $\left.\mathrm{L}^{-1}\right)$ and JW $\left(0.1 \times 10^{5}-7.3 \times 10^{5}\right.$ cells. $\left.\mathrm{L}^{-1}\right)$ expectedly were significant (Tab. 3b). The JW algal assemblage was dominated by Encionema ventricosa $\left(510-8 \times 10^{5}\right.$ cells. $\left.\mathrm{L}^{-1}\right)$, whereas at the JS this species appeared sporadically. Correlations between the sestonic algal abundance and environmental parameters were not significant.

\section{Protozoan and meiofaunal assemblages in the epiphyton and seston}

In bryophyte epiphyton samples, we recorded a total of 55 taxa of Protozoa and 24 taxa of meiofauna (Appendix 1). S at the JS was very low (Protozoa $8 \pm 2$ taxa, meiofauna $3 \pm 2$ taxa), whereas at the JW it was twofold higher (Fig. 2). During the year SI between JS and JW for Protozoa ranged from $19 \%$ to $46 \%$ and for meiofauna from $15 \%$ to $60 \%$, mostly indicating low similarity between the sites.

Ciliophora were the most diverse (39 taxa) and abundant group at both investigated sites (JS 299 \pm 198 ind.cm ${ }^{-2}$, JW $701 \pm 571$ ind.cm ${ }^{-2}$ ) without established significant spatial difference (Mann-Whitney $U$ test, $\left.Z=-1,148 ; N_{\mathrm{JS}, \mathrm{JW}}=9, P=0.251\right)$. At the JS, Sarcodina $\left(86 \pm 94\right.$ ind.cm $\left.{ }^{-2}\right)$, Protozoa $\left(375 \pm 266\right.$ ind.cm $\left.{ }^{-2}\right)$, Rotifera $\left(59 \pm 42\right.$ ind.cm $\left.{ }^{-2}\right)$, Nematoda $\left(71 \pm 52\right.$ ind.cm $\left.{ }^{-2}\right)$ and meiofauna $\left(85 \pm 91\right.$ ind.cm $\left.{ }^{-2}\right)$ were in significantly lower abundance than at the JW (Sarcodina $322 \pm 468$ ind. $\mathrm{cm}^{-2}$, protozoa $1023 \pm 883$ ind.cm ${ }^{-2}$, Rotifera $557 \pm 537$ ind.cm ${ }^{-2}$, Nematoda $262 \pm 336$ 'ind.cm $^{-2}$, meiofauna $832 \pm 840$ ind.cm ${ }^{-2}$ ) (Fig. 3, Tab. 3a).

According to the seasonality, both communities at the JS reached maximum abundance in May, whereas Protozoa reached a peak in September. At the sampling site JW, meiofaunal and protozoan abundances also peaked in spring (Fig. 3). We suppose significant Ciliophora seasonal variation (Kruskal-Wallis test, $H$ (3, $N=18)=11.3, P=0.010)$ implicated seasonal variations in protozoan abundance (Tab. 3a).

In the seston assemblage dominated Rotifera (30 taxa) followed by Ciliophora (15 taxa) (Appendix 2). At the spring site, JS, low abundances of all seston groups were noted $\left(0.66 \pm 1.35\right.$ ind. $\left.\mathrm{L}^{-1}\right)$. At the stream outflow abundance increased (JW $206 \pm 325$ ind. $\mathrm{L}^{-1}$ ) and adducted to significant differences in abundance of Protozoa, Rotifera, heterogenic group of organisms (Others) and meiofauna (Fig. 4 and Tab. 3b). 
Table 3. Spatial (Mann-Whitney $U$ test, $N_{\text {JS, JW }}=9$, Abb. MW) and seasonal (Kruskal-Wallis test, $N=18$, Abb. K-W) differences in abundance of investigated organisms in (a) bryophyte communities and in (b) seston, both showed according to significant spatial differences.

\begin{tabular}{|c|c|c|}
\hline Sites (JS-JW) Seasons & $Z_{M-W} H_{K-W}$ & $P$ \\
\hline \multicolumn{3}{|c|}{ (a) Bryophyte communities } \\
\hline \multicolumn{3}{|l|}{ ALGAE } \\
\hline Sites & -2.473 & 0.0134 \\
\hline Seasons & 4.681 & 0.1967 \\
\hline \multicolumn{3}{|l|}{ Cyanobacteria } \\
\hline Sites & $-2,119$ & 0.0340 \\
\hline Seasons & 6.12 & 0.1058 \\
\hline \multicolumn{3}{|l|}{ Bacillarophyceae } \\
\hline Sites & -2.030 & 0.0423 \\
\hline Seasons & 7,830 & 0.0497 \\
\hline \multicolumn{3}{|l|}{ Achnanthidium spp. } \\
\hline Sites & $-3,444$ & 0.0006 \\
\hline Seasons & 2.31 & 0.5112 \\
\hline \multicolumn{3}{|l|}{ Cocconeis placentula } \\
\hline Sites & 3,002 & 0.0027 \\
\hline Seasons & 3.409 & 0.3327 \\
\hline \multicolumn{3}{|l|}{ Chlorophyta } \\
\hline Sites & $-2,208$ & 0.0272 \\
\hline Seasons & 2.66 & 0.4470 \\
\hline \multicolumn{3}{|c|}{ PROTOZOA + MEIOFAUNA } \\
\hline Sites & -1.943 & 0.0500 \\
\hline Seasons & 9.769 & 0.0206 \\
\hline \multicolumn{3}{|l|}{ Aspidisca spp. } \\
\hline Sites & -2.119 & 0.0340 \\
\hline Seasons & 7.073 & 0.0700 \\
\hline \multicolumn{3}{|l|}{ Sarcodina } \\
\hline Sites & -2.472 & 0.0134 \\
\hline Seasons & 2.751 & 0.4316 \\
\hline \multicolumn{3}{|l|}{ Meiofauna } \\
\hline Sites & -3.113 & 0.0009 \\
\hline Seasons & 1.22 & 0.7491 \\
\hline \multicolumn{3}{|l|}{ Rotifera } \\
\hline Sites & -3.444 & 0.0006 \\
\hline Seasons & 1.257 & 0.7393 \\
\hline \multicolumn{3}{|l|}{ Colurella sp. } \\
\hline Sites & -3.046 & 0.0023 \\
\hline Seasons & 0.427 & 0.9347 \\
\hline \multicolumn{3}{|l|}{ Bdelloidea } \\
\hline Sites & -3.267 & 0.0011 \\
\hline Seasons & 0.233 & 0.9721 \\
\hline \multicolumn{3}{|l|}{ Nematoda } \\
\hline Sites & -2.826 & 0.0050 \\
\hline Seasons & 1.378 & 0.7108 \\
\hline \multicolumn{3}{|l|}{ Others } \\
\hline Sites & -2.104 & 0.0354 \\
\hline Seasons & 5.186 & 0.1586 \\
\hline \multicolumn{3}{|c|}{ BENTHIC MACROINVERTEBRATES } \\
\hline Sites & -2.589 & 0.0100 \\
\hline Seasons & 0.246 & 0.9700 \\
\hline
\end{tabular}

\begin{tabular}{lcc}
\hline Sites (JS-JW) Seasons & $Z_{M-W} H_{K-W}$ & $P$ \\
\hline (b) Seston & & \\
Algae & & \\
Sites & -3.576 & 0.0003 \\
Seasons & 0.181 & 0.9810 \\
Protozoa & & \\
Sites & -2.997 & 0.0027 \\
Seasons & 1,254 & 0.7400 \\
Rotifera & & \\
Sites & -3.539 & 0.0004 \\
Seasons & 0.981 & 0.8060 \\
Others & & \\
Sites & -2.495 & 0.0126 \\
Seasons & 2.096 & 0.5530 \\
Meiofauna & & \\
Sites & -3.584 & 0.0003 \\
Seasons & 1.391 & 0.7075 \\
\hline
\end{tabular}

In the seston flux abundance of euplanktonic and semiplanktonic organisms increased through the reservoirs (R1 and R2), while benthic organisms decreased (Fig. 5). Sørensen similarity index between R2 and JW averaged $65 \%$ for euplanktonic and semiplanktonic taxa. Following Mann-Whitney $U$ test, between seston at the R2 and JW non-significant differences in abundances of semiplanktonic $(P>0.05)$ and benthic $(P>0.05)$ organisms were exhibited, while euplanktonic organisms significantly decreased $\left(Z=2.031, N_{\mathrm{R} 2, \mathrm{JW}}=9, P<0.0423\right)$. Positive correlation in seston suggested abundance of heterogenic group of organisms and flow velocity $(R=0.765, N=9, P<0.05)$.

\section{Macroinvertebrate assemblages in the bryophyte community and seston}

We identified 25 taxa, 14 of which were exclusive to the spring site, JS, 4 to the waterfall site, JW, while 7 taxa were common for both sites (Appendix 1). Contrary to the above investigated groups in epiphyton, macroinvertebrate $\mathrm{S}$ was higher in dense, JS $(6 \pm 4$ taxa) than in scattered, JW ( $3 \pm 2$ taxa) bryophyte cover (Fig. 2). The SI between JS and JW varied greatly $(0-80 \%)$ and averaged around $23 \%$.

Gammarus fossarum and Elmis aenea were found only at the spring (JS), where their abundance amounted to more than $70 \%$ of the total catch (Appendix 1). At the waterfall site (JW), Chironomidae represented more than half of the total catch and together with Oligochaeta more than three-quarters of the total catch. Of the 7 common taxa only Chironomidae were significantly more abundant at the waterfall site, whereas all of the other taxa were similar in abundance at both sites. Even though the mean abundance of Oligochaeta was two orders of magnitude greater at the waterfall site, JW $\left(144 \pm 305\right.$ ind. $\left.\mathrm{m}^{-2}\right)$ than at the JS $\left(1 \pm 3\right.$ ind $\left.\mathrm{m}^{-2}\right)$, this was not found to be statistically significant (Tab. 3a).

Benthic macroinvertebrates were only found in the seston sporadically at the JS and then only Protonemura 

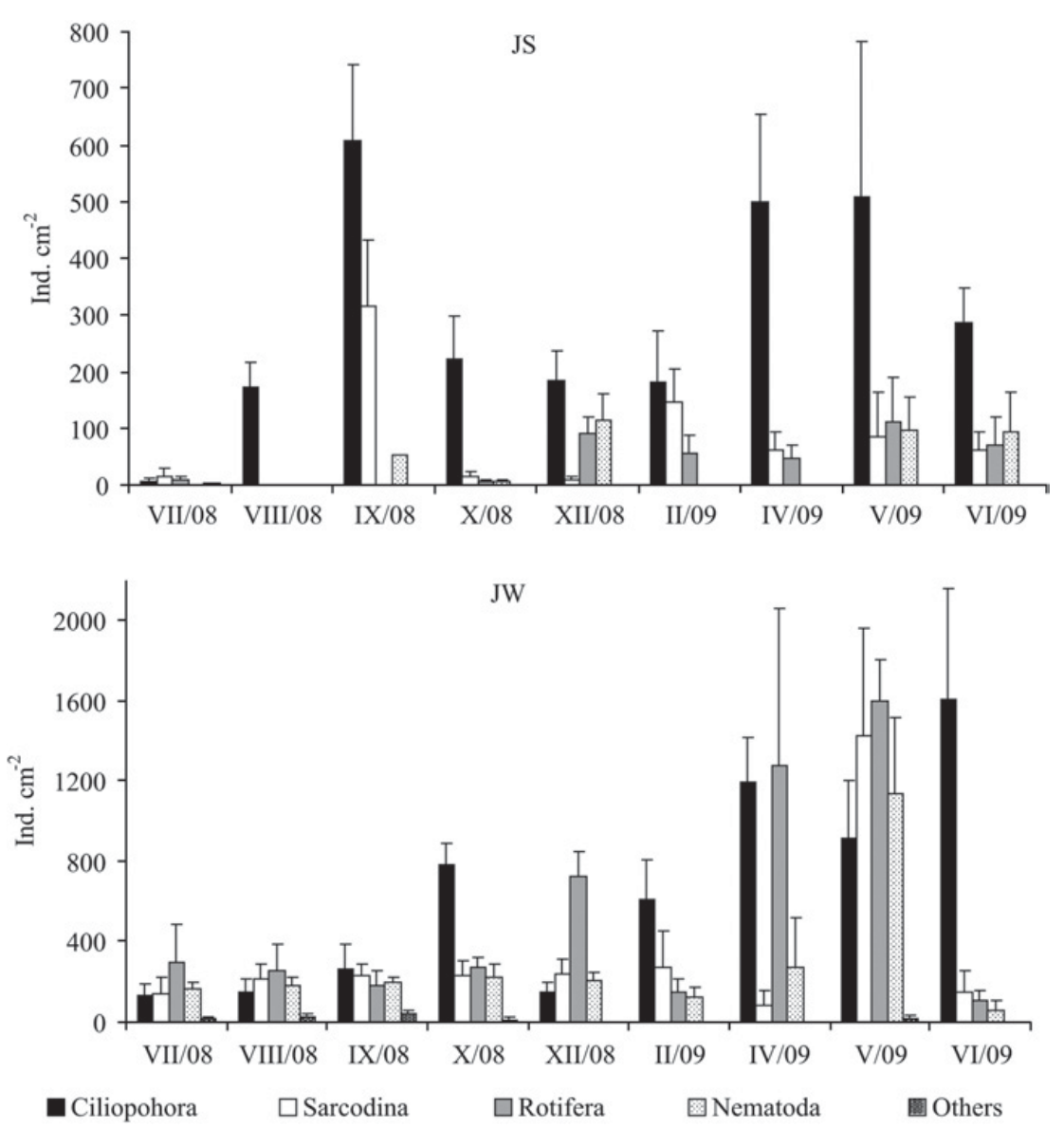

Fig. 3. Mean abundances of protozoa and meiofauna (Rotifera, Nematoda and Others) in bryophyte communities at JS and JW sites. Roman numerals mark months and joined Arabic numbers mark year of sampling. Mean values and standard error bars are of triplicates.

sp. and Chironomidae were found. At the waterfall site benthic macroinvertebrates were more common as every sample contained drifting macroinvertebrates and five taxa were found in total (Appendix 2). Still, this difference in drift was not significant. We did not find any significant relationship between the abundance of any of the taxa in the seston samples and the environmental conditions or with the abundance of the respective taxa in the benthic habitats.

\section{Interactions between the bryophyte communities and environmental parameters}

According to Spearman correlations and in agreement with BIO-ENV analysis, S at the JS was best explained by flow velocity $\left(q_{w}=0.461\right)$ and its interaction with epiphyton amount, AFDMe $\left(q_{\mathrm{w}}=0.448\right)$ (Tab. 4). Therein, $\mathrm{S}$ was affected negatively by flow velocity while positively by AFDMe. At the JW non-significant relationships were noted between $\mathrm{S}$ and environmental parameters. Consequently, it reflected in low correlation between $\mathrm{S}$ and AFDMs $\left(q_{\mathrm{w}}=0.147\right)$ (Tab. 4).

NMDS ordination based on abundance similarity suggested clustering of most macroinvertebrates groups
(Amphipoda, Ephemeroptera, Plecoptera, Coleoptera group I) achieving higher abundances in dense bryophyte clusters (JS) compared with scattered ones, at the JW (Fig. 6). Of the macroinvertebrate groups, Amphipoda, Coleoptera and Ephemeroptera were negatively affected by flow velocity $(R=-0.19$ to $-0.58, N=9, P>0.05)$ at the JS. Also, at the JS, pH negatively affected macroinvertebrate abundance $(R=-0.10$ to -0.25 , $N=9, P>0.05$ ) (Tab. 4). These findings corroborated with results of BIO-ENV analysis where flow velocity and $\mathrm{pH}\left(q_{\mathrm{w}}=0.441\right)$ best explained organisms abundances at the JS (Tab. 4). On the contrary, in NMDS plot, algae (Cyanobacteria, Bacillariophyceae and Chlorophyta), Protozoa (Ciliophora and Sarcodina), meiofauna (Rotifera, Nematoda and Others) and macroinvertebrates (Oligochaeta and Diptera) are associated in group II, reaching higher abundance in scattered bryophyte clusters, at the JW (Tab. 2, Fig. 6). High algal abundance at the JW is best explained by significant and positive correlations with nutrient concentrations, nitrates and orthophosphates (Tab. 4). Moreover, significant positive correlation with algal abundance ordinated Ciliophora and Rotifera at the JW site (Tab. 4). Proximity of Diptera and Cynobacteria in the plot indicated their positive relationship $(R=0.68, N=9, P<0.05)$. We assume that these 

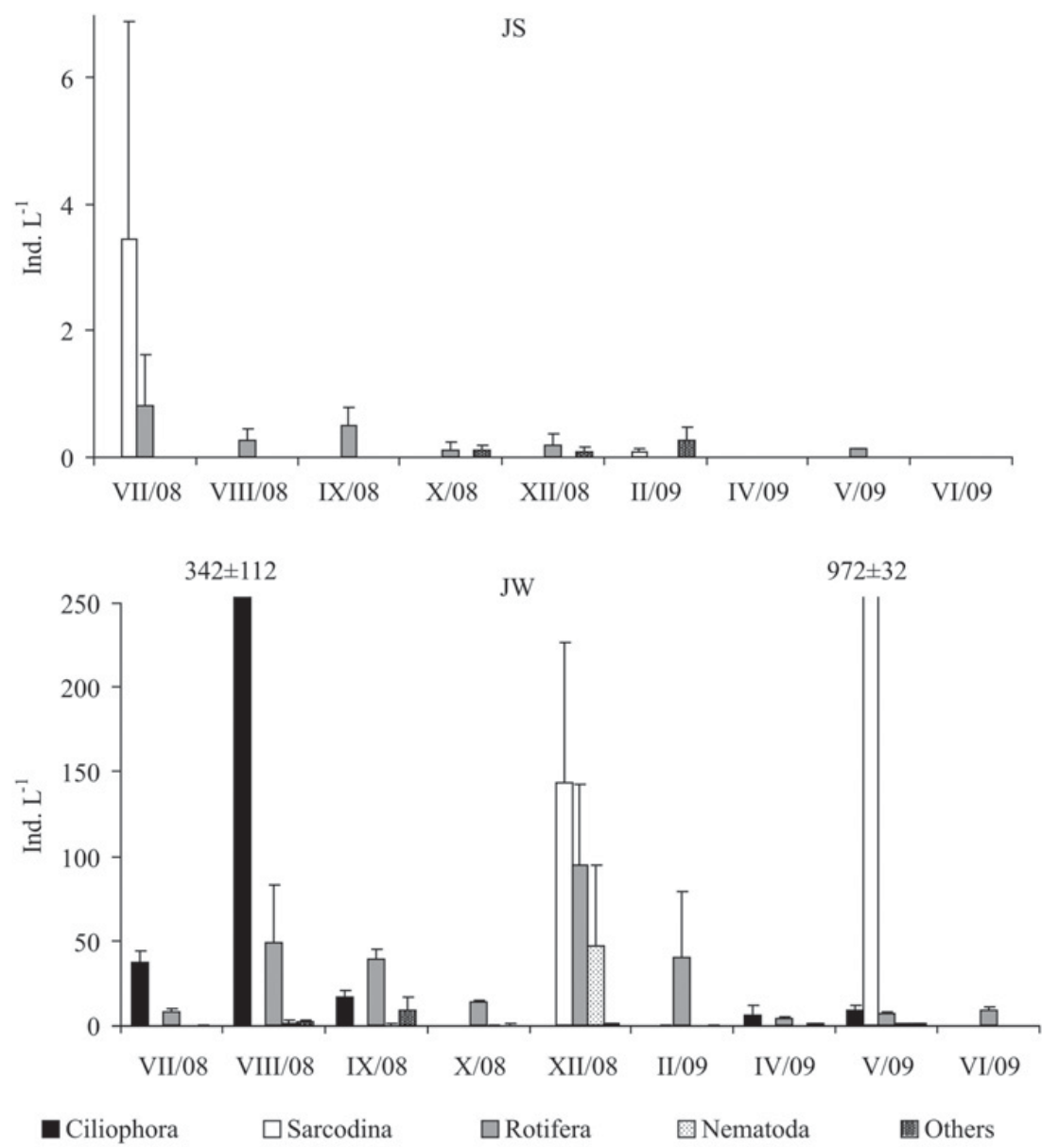

Fig. 4. Mean abundances of protozoa, Rotifera, Nematoda and Others in seston at JS and JW sites. Roman numerals mark months and joined Arabic numbers mark year of sampling. Mean values and standard error bars are of triplicates.

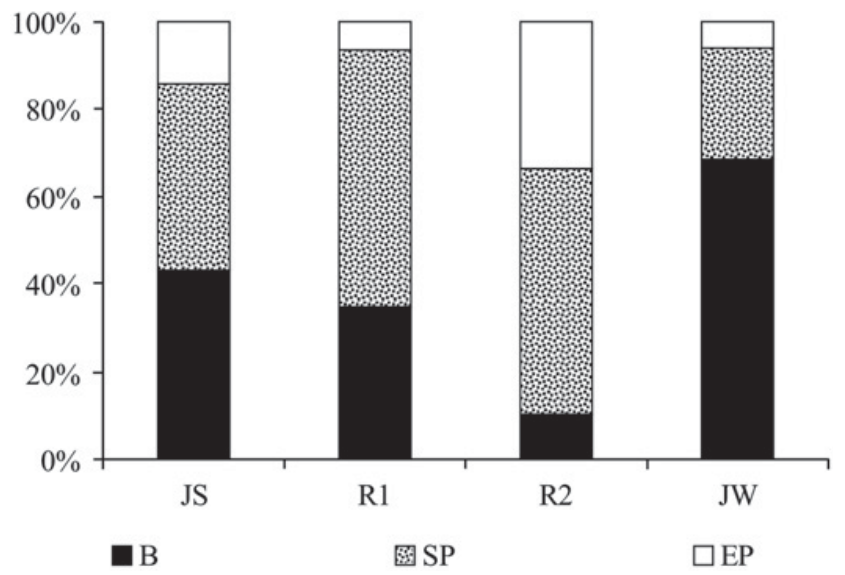

Fig. 5. Relative abundance of euplanktonic, semiplanktonic and benthic organisms in seston along investigated longitudinal profile in Jankovac Stream. Abbreviations: B, benthic; SP, semiplanktonic; EP, euplanktonic organisms.

organisms constituted subgroup IIA due to positive correlations with nutrients and algae (Fig. 6). The subgroup IIB is characterized by exclusively benthic organisms, Oligochaeta and Nematoda, which prefer detritus particles, suggested by positive correlation with
AFDMe, $R=0.42$ and 0.57 , respectively $(N=9, P>0.05)$ (Fig. 6). Results of Spearman correlations and NMDS plot corroborate with the BIO-ENV procedure presenting biocoenosis abundance in the scattered bryophyte clusters, at the JW, as the most affected by organic matter in seston and in epiphyton $\left(q_{\mathrm{w}}=0.353\right)$.

\section{Discussion}

We investigated two sampling sites in different lotic stretches according to their hydromorphological features (flow velocity, slope and bryophyte cover). In comparison with other authors (Suren 1993; Linhart et al., 2002), data presented in our study provide an entire overview of the diversity and abundance of autotrophic and heterotrophic components, i.e., algae, Protozoa, meiofauna and macroinvertebrates of bryophyte communities in karst running water.

\section{Environmental conditions}

The two investigated sites differed markedly in their water chemistry, nutrients and food supplies. A higher alkalinity, free $\mathrm{CO}_{2}$, together with a lower $\mathrm{pH}$ at the spring 
Table 4. Spearman correlations between environmental parameters and $\mathrm{S}$ or abundances of main groups in bryophyte communities $\left(N_{\mathrm{JS}, \mathrm{JW}}=9\right)$. Only significant correlations $(P<0.05)$ are shown.

\begin{tabular}{|c|c|c|c|c|c|}
\hline & & \multicolumn{4}{|c|}{ Species richness (No. of taxa) } \\
\hline & & Algae & Protozoa & Meiofauna & Macroinvertebrates \\
\hline Flow velocity $\left(\mathrm{cm} . \mathrm{s}^{-1}\right)$ & JS & -0.67 & & & -0.67 \\
\hline \multirow[t]{3}{*}{ AFDWe $\left(\times 10^{3} \mathrm{mg} \cdot \mathrm{cm}^{-2}\right)$} & JS & & 0.67 & & \\
\hline & & \multicolumn{3}{|c|}{ Abundance (Ind. $\mathrm{cm}^{-2}$ ) } & Abundance (Ind.m ${ }^{-2}$ ) \\
\hline & & $\overline{\text { Algae }}$ & Protozoa & Meiofauna & $\overline{\text { Macroinvertebrates }}$ \\
\hline $\mathrm{pH}$ & JS & & & 0.73 & \\
\hline$\left(\mathrm{N}-\mathrm{NO}^{3-}\right)\left(\mathrm{mg} \cdot \mathrm{L}^{-1}\right)$ & JW & 0.84 & & & \\
\hline$\left(\mathrm{P}-\mathrm{PO} 4^{3-}\right)\left(\mathrm{mg} \cdot \mathrm{L}^{-1}\right)$ & JW & 0.67 & & & \\
\hline Flow velocity $\left(\mathrm{cm} . \mathrm{s}^{-1}\right)$ & JS & & & & -0.67 \\
\hline $\operatorname{AFDMs}\left(\times 10^{3} \mathrm{mg} \cdot \mathrm{L}^{-1}\right)$ & JS & & & 0.76 & \\
\hline & JW & & & 0.68 & \\
\hline $\operatorname{AFDMe}\left(\times 10^{3} \mathrm{mg} \cdot \mathrm{cm}^{-2}\right)$ & JS & & 0.70 & 0.67 & \\
\hline & JW & & 0.68 & 0.67 & \\
\hline Ciliophora (Ind.cm ${ }^{-2}$ ) & JW & 0.72 & & & \\
\hline Rotifera (Ind.cm ${ }^{-2}$ ) & JW & 0.67 & & & \\
\hline
\end{tabular}

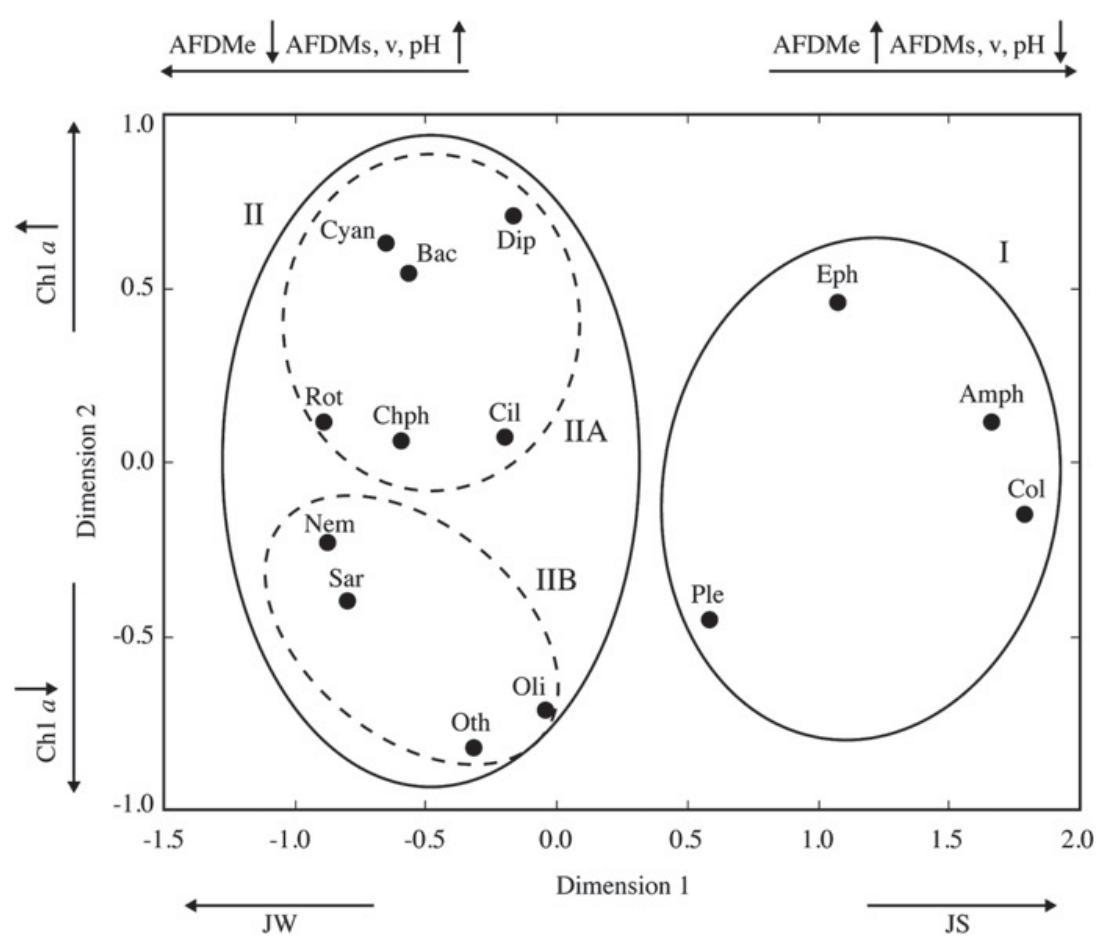

Fig. 6. NMDS ordination according to abundance of main group of algae, protozoa, meiofauna and macroinvertebrates in bryophyte communities (stress: 0.1). Legend of abbreviations to organism groups by alphabetic order: Amph, Amphipoda; Bac, Bacillariophyceae; Cil, Ciliophora; Chph, Chlorophyta; Col, Coleoptera; Cya, Cyanobacteria; Dip, Diptera; Eph, Ephemeroptera; Nem, Nematoda; Oli, Oligochaeta; Ple, Plecoptera; Rot, Rotifera; Sar, Sarcodina.

site, contrary to the waterfall site, may be connected to the rise of $\mathrm{CO}_{2}$-rich groundwater to surface, tufa deposition at the waterfall barrier and the chemistry of karst water (Srdoč et al., 1985; Matoničkin Kepčija et al., 2006). High concentration of nitrate is natural and habitual to springs, especially in the karst system (Malard et al., 1997). On the other hand, the waterfall site was located after two reservoirs. These water bodies changed the environmental conditions with regard to significantly higher, orthophosphates, suspended organic matter and Chl $a$ concentrations. According to the findings of other authors (Zimmermann-Timm et al., 2007), lentic parts enriched downstream lotic stretch in running waters with nutrients and organic matter, especially where lentic stretches prevailed over lotic, as in the Jankovac hydrosystem alike Plitvice lakes, Croatia (Špoljar et al., 2007a, b).

\section{Biocoenosis diversity and abundance in two bryophyte microhabitats}

Bryophytes in running waters could be compared with macrophytes in lentic systems, as both are characterized by an epiphytic layer, i.e., food for Protozoa and 
metazoan invertebrates and their role as a refuge from predators and environmental stressors (KuczyńskaKippen, 2005; Miliša et al., 2006a; Špoljar et al., 2011). Two investigated microhabitats consisted of different bryophyte covers resulting in higher diversity and abundance of algae, Protozoa and meiofauna in scattered bryophyte clusters at the waterfall site, whereas macroinvertebrates showed higher diversity and abundance in dense bryophyte clusters. Flow velocity was expressed as a factor that strongly negatively affected macroinvertebrate richness and abundance in dense bryophyte clusters; these results correspond to the findings of Habdija et al. (2004). The higher diversity and abundance in scattered bryophyte clusters, at the JW, can be explained by the impact of upstream reservoirs and streambed drift. We confirmed our results by statistical analyses that indicated influence of suspended organic mater (algae, detritus and bacteria) on diversity and abundance in scattered bryophyte clusters. Namely, the longer water residence time coupled with higher nutrient concentrations and submerged vegetation in the upstream reservoirs allowed the development of plankton, thus causing higher diversity and abundance at the waterfall site (Basu et al., 2000). Significant downstream drop of euplanktonic organisms in seston, at the transition from R2 to JW, indicated their sedimentation, e.g., in bryophyte clusters. On the contrary, high inclination of upstream stretch contributed to higher flow velocity and supported the drift of benthic organisms (Špoljar et al., 2007b; Sertić Perić et al., 2011).

\section{Algae}

The proximate factors controlling benthic algae in running waters can be divided into the regulating processes of abundance accrual such as nutrients (Stanley et al., 1990; Kralj et al., 2006) and those regulating the counteracting processes of biomass loss such as flow velocity (Stevenson et al., 1996). This is in agreement with our results where flow velocity negatively influenced algal diversity and abundance, while nutrients had positive impact on the abundance. Moreover, this study showed the typical colonization sequence for streams (Keithan and Lowe, 1985), with the small monoraphid and araphid pennate Bacillariophyceae (Achnanthidium and Diatoma) being dominant at the beginning of colonization for both spring (JS) and waterfall (JW) sites. The low-growing diatom $C$. placentula as the most abundant diatom in the spring site is usually reported as an early colonist (Stevenson et al., 1996). Summer drop of algae at the JS could be explained by grazing of Coleoptera larvae E. aenea and Plecoptera larvae on diatoms and Cyanobacteria indicated by negative correlation for both $(R=-0.67, \quad N=9, \quad P<0.05)$. Dominance of typical epiphytic species from genus Achnanthidium in scattered bryophyte cluster is explained by its resistance to dislodgement by current-induced shear forces (Soininen, 2004). The JW was obviously dominated by the passive settlement of cells that are governed by a suitable propagule pool related to the abundance of cells in the upstream reservoirs (Basu and Pick, 1996). The net-like bryophyte substrata accumulated and maintained a high algal diversity and abundance and probably trapped algae drifting in the seston, which is in compliance with results of provided analyses (Burkholder and Sheath, 1984).

\section{Protozoa and meiofauna}

In our investigation, among Sarcodina, testate amoebae, from genera Euglypha and Centropyxis together with Actinophrys sol, a member of Helioza, were dominant in bryophyte communities, similar to findings of other authors in aquatic bryophytes (Page and Siemensma, 1991; Glime, 2007). According to Sleight et al. (1992), $75 \%$ of protozoan production in stream benthos belongs to ciliates, and it is pursuant to results in the bryophytes of Jankovac Stream where Ciliophora constituted majority of the abundance. Small, widespread species such as Aspidisca lynceus, Cinetochilum margaritaceum and Glaucoma scintillans prevailed among the Ciliophora in JS and JW, which is in concordance with findings of Krno et al. (2006).

Meiofaunal communities in bryophyte clusters of Jankovac Stream were dominated by rotifers ( $>50 \%$ in the total abundance of meiofauna) and nematodes, while other groups of meiofauna were in low abundance comparable to Palmer (1990) and Rundle et al. (2002). Considering Monogononta-Bdelloidea ratio, dominance of bdelloids (average 60\%) was established, in particular at the JW, in scattered bryophyte coverage. Linhart et al. (2002) found similar results in bryophytes in two streams, first in the Czech Republic (Bystrice Stream) and the second in Austria (Stream Oberer Seebach). In other freshwater substrates, bdelloids contributed in lower amounts, of 20-30\% (Ricci, 1987). We interpret high bdelloids abundance in scattered bryophyte clusters by their positive relation with flow velocity $(R=0.50 ; N=18$, $P<0.05)$, algae $(R=0.59, N=18, P<0.05)$ and suspended organic matter $(R=0.70, N=18, \quad P<0.05)$. According to the feeding guild, bdelloids feed on algae, bacteria and yeasts by filtering, scraping and browsing (Wallace and Ricci, 2002), therefore they can utilize food from the benthos as well as from the seston (Strayer et al., 1997). Bdelloids tolerance to fast flow velocity was established also in low-ordered stream with bryophyte cover as positive or not-significant relationship (Linhartová et al., 2005). The abundance of moss-dwelling meiofauna found in the scattered bryophyte cluster of Jankovac Stream was ten-fold higher than the abundance of meiofauna found in other types of substrates (Reiss and Schmid-Araya, 2008) or even in some bryophytes (Suren, 1992). Our results are comparable with those of Linhart et al. (2002), who also found high meiofaunal abundance in stream bryophytes $\left(>3.5 \times 10^{6}\right.$ ind. $\left.\mathrm{m}^{-2}\right)$. Moreover, Dumnicka et al. (2007) concluded that substratum type was found to be the main discriminatory factor with regard to the fauna density, while faunal composition was related to the geographical position of the springs. 


\section{Macroinvertebrates}

In dense bryophyte clusters at the JS, deposited organic matter was mainly of allochthonous origin (leaf litter) and hence $G$. fossarum and $E$. aenea were dominant species since they both feed on it (Moog, 2002). G. fossarum, a species with reophilous characteristics, apparently was affected by flow velocity more than E. aenea (Schmedtje, 1995, Miliša et al., 2010). Two shallow reservoirs presented an insurmountable obstacle for the downstream dispersal of $G$. fossarum. Thus macroinvertebrates, as sensitive indicator of hydromorphological disturbance, were most affected by longitudinal discontinuities (dams, backwaters and reservoirs), which can impede downstream dispersion of macroinvertebrates (Bednarek and Hart, 2005). In scattered bryophyte clusters, abundance of Chironomidae significantly increased probably due to their filtering guilds and food preference to suspended organic matter (Moog, 2002), as well as wide positive effect of plenty Cyanobacteria in JW and high range of tolerance of Chironomidae to flow velocity (Collier, 1993).

\section{Seston in stream advection}

To analyse bioseston in particular conditions of environmental parameters and low production, we sampled source seston and found low abundance and just few taxa of ubiquitous organisms, mainly rotifers (Wilhartitz et al., 2009). Accordingly, the outflow site, mouth of Jankovac Stream, was very diverse with regard to $\mathrm{S}$ and abundance. It consisted of mixed assemblage of planktonic and benthic organisms as reflection of seston production in upstream reservoirs and drift of bryophyte covered lotic stretch similar to Sandlund (1982) and Špoljar et al. (2007b). Thus, we explained higher abundance of heterogenic group of organisms, mainly consisting of benthic organisms, by streambed drift, implicated in positive relation with flow velocity at the waterfall site.We assume that upstream reservoirs conducted role of organic matter source, increase in abundance of all groups of investigated organisms, except Amphipoda and insect larvae, and thereby seston role in downstream food transport. Smith and Brown (2006) also reported increase in meiofauna abundance in seston at higher flow velocity and role of seston in meiofaunal colonization of new substrates. Recently, it was also demonstrated that bryophytes play a role in dispersal (Sertić Perić et al., 2011). In habitats with moss covered bed, only a few animals enter the drift and most are transferred downstream with broken moss mats to which they cling (insect larvae) or in which they are entangled (Oligochaeta). According to our results, there is evidently a decrease of semi- and euplanktonic organisms at the JW in comparison with the upstream reservoirs (R1 and R2). We suppose that planktonic organisms in lotic stretch, apart from sedimentation, could be accidentally trapped by cauloids and phylloids of the bryophyte clusters.

\section{Conclusions}

This study was most comprehensive investigation of bryophytic community as it involved algae, protozoa, meiofauna and macroinvertebrates in two microhabitats of karst headwater stream. In dense bryophyte cover (e.g., the spring site), $\mathrm{S}$ and abundance were affected by flow velocity and $\mathrm{pH}$. In such conditions, in the absence of high primary production, higher diversity and abundance accomplished macroinvertebrates. In scattered bryophyte clusters, subsequent to influence of lentic and lotic stretches, community accomplished higher abundance and diversity, governed primarily by amount of suspended organic matter and epiphyton. Jankovac Stream as loticlentic hydrosystem is very interesting for seston investigation, and we may corroborate importance of seston in downstream food transport and organisms dispersion. Lastly, but not less importantly, anthropogenic impact in streambed hydromorphology is highly manifested in macroinvertebrate assemblage disturbance.

Acknowledgements. This study was funded by the Papuk Nature Park and the project 11900000001205 (by Professor Ivan Habdija) of the Ministry of Education, Science and Sport, Republic of Croatia. We thank the personnel of the Papuk Nature Park for their help in administrative and field support. We are thankful to Assistant Professor Jasna Lajtner for determination of Gastropoda, mag. oecol. Juraj Boljat and technician Svjetlana Vidović for macroinvertebrate isolation. We are especially grateful to Professor Robert L. Wallace (Ripon College, Wisconsin, USA) for his valuable comments that improved the quality of the manuscript. Finally, we thank the two anonymous referees on the helpful and constructive comments in manuscript structuring.

\section{References}

Adl S.M., Simpson A.G.B., Farmer M.A., Andersen R.A., Anderson O.R., Barta J.R., Bowser S.S., Brugerolle G., Fensome R.A., Fredeicq S., James T.Y., Karpov S., Kugrens P., Krug J., Lane C.E., Lewis L.A., Lodge J., Lynn D.H., Mann D.G., Mccourt R.M., Mendoza L., Moenstrup Ø., Mozley-Standridge S., Nerad T.A., Shearer C.A., Smirnov A.V., Spiegel F.W. and Taylor M.J.R., 2005. The new higher level classification of eukaryotes with emphasis on the taxonomy of protists. J. Euk. Microb., 52, 399-451.

APHA, 1985. Standard Methods for the Examination of Water and Waste (12th edn), American Public Health Association, New York, 1268 p.

Basu B.K., Kalff J. and Pinel-Alloul B., 2000. The influence of macrophyte beds on plankton communities and their export from fluvial lakes in the St. Lawrence River. Freshw. Biol., 45, 373-382.

Basu B.K. and Pick F.R., 1996. Factor regulating phytoplankton and zooplankton biomass in temperate rivers. Limnol. Oceanogr., 41, 1572-1577.

Bauernfeind E. and Humpesch U.H., 2001. Die Eintagsfliegen Zentraleuropas (Insecta: Ephemeroptera): Bestimmung und 
Ökologie, Verlag des Naturhistorischen Museums, Wien, $239 \mathrm{p}$.

Bednarek A.T. and Hart D.D., 2005. Modifying dam operations to restore rivers: ecological responses to Tennessee River dam mitigation. Ecol. Appl., 15, 997-1008.

Bogut I., Čerba D., Vidaković J. and Gvozdić V., 2010. Interactions of weed-bed invertebrates and Ceratophyllum demersum L. stands in a floodplain lake. Biologia, 65, 113-121.

Bowden B., Glime J.M. and Riis T., 2006. Macrophytes and bryophytes. In: Hauer F.R. and Lamberti G.A. (eds.), Methods in Stream Ecology, Elsevier, London, 381-414.

Breitig G. and von Tümpling W., 1982. Ausgewaehlte Methoden der Wasseruntersuchung, Band II. Biologische, Mikrobiologische und Toxikologische Methoden, VEB Gustav Fischer Verlag, Jena, 579 p.

Burkholder J.M. and Sheath R.G., 1984. The seasonal distribution, abundance and diversity of desmids (Chlorophyta) in a softwater, north temperate stream. J. Phycol., 20, 159172.

Clarke K.R. and Gorley R.N., 2006. PRIMER v6: User Manual/ Tutorial. PRIMER-E, Plymouth, 192 p.

Collier K.J., 1993. Flow preferences of larval Chironomidae (Diptera) inTongariro River, New Zealand. N. Z. J. Mar. Freshw. Res., 27, 219-226.

Descy J.P., Everbecq E., Gosselain V, Viroux L. and Smitz J.S., 2003. Modelling the impact of benthic filter-feeders on the composition and biomass of river plankton. Freshw. Biol., 48, 404- 417.

Donner P.J., 1972. Die Rädertierbestände submerser Moose und weiterer Merotope im Bereich der Stauraüme der Donau an der Deutch-Österreichischen Landesgrenze. Arch. Hydrobiol. Suppl., 44, 49-114.

Duggan I.C., 2001. The ecology of periphytic rotifers. Hydrobiologia, 446/447, 139-148.

Dumnicka E., Galas J. and Koperski P., 2007. Benthic invertebrates in Karst Springs: does substratum or location define communities? Int. J. Lim., 92, 452-464.

Einsle U., 1993. Crustacea, Copepoda, Calanoida und Cyclopoida, Gustav Fischer Verlag, Berlin, 209 p.

Fenchel T.M., 1978. The ecology of micro- and meiobenthos. Annu. Rev. Ecol. Syst., 9, 99-121.

Foissner W. and Berger H., 1996. A user-friendly guide to the ciliates (Protozoa, Ciliophora) commonly used by hydrobiologists as bioindicators in rivers, lakes, and waste waters, with notes on their ecology. Freshw. Biol., 35, 375482.

Glime J.M., 2007. Bryophyte Ecology. Volume 2. Bryological Interaction. Ebook sponsored by Michigan Technological University and the International Association of Bryologists. http://www.bryoecol.mtu.edu/.

Glöer P., 2002. Die Süsswassergastropoden Nord-und Mitteleuropas. In: Bestimmungsschlüssel, Lebensweise, Verbreitung, ConchBooks, Hackenheim, 326 p.

Habdija I., Primc-Habdija B., Matoničkin R., Kučinić M., Radanović I., Miliša M. and Mihaljević Z., 2004. Current velocity and food supply as factors affecting the composition of macroinvertebrates in bryophyte habitats in karst running water. Biologia, 59, 577-593.

Hakenkamp C.C. and Morin A., 2000. The importance of meiofauna to lotic ecosystem functioning. Freshw. Biol., 43, 165-175.
Höll K., 1986. Wasser Untersuchung, Beurteilung, Aufbereitung, Chemie, Bakteriologie, Virologie, Biologie (7th edn), Walter de Gruyter Verlag, Berlin, 393 p.

John D.M., Whitton B.A. and Brook A.J., 2002. The Freshwater Algal Flora of the British Isles: An Identification Guide to Freshwater and Terrestrial Algae, Cambridge University Press, New York, 714 p.

Keithan E.D. and Lowe R.L., 1985. Primary productivity and spatial structure of phytolithic growth in streams in the Great Smoky Mountains National Park, Tennessee. Hydrobiologia, 123, 59-67.

Knapp J.M. and Lowe R.L., 2009. Spatial distribution of epiphytic diatoms on lotic bryophytes. Southeast. Nat., 8, 305-316.

Komárek J. and Anagnostidis K., 1999. Süßwasserflora von Mitteleuropa: Band 19/1: Cyanoprokaryota 1. Teil: Chroococcales, Gustav Fischer Verlag, Stuttgart, 548 p.

Komárek J. and Anagnostidis K., 2005. Süßwasserflora von Mitteleuropa: Band 19/2: Cyanoprokaryota 2. Teil: Oscillatoriales, Gustav Fischer Verlag, Stuttgart, 759 p.

Koste W., 1978. Die Rädertiere Mitteleuropas, Gebrüder Borntraeger. Berlin, Stuttgart, 673 p.

Kralj K., Plenković-Moraj A., Gligora M., Primc-Habdija B. and Sipos L., 2006. Structure of periphytic community on artificial substrata: influence of depth, slide orientation and colonization time in karstic Lake Visovačko, Croatia. Hydrobiologia, 560, 249-258.

Krammer K. and Lange-Bertalot H., 1986. Bacillariophyceae. 1. Teil: Naviculaceae. In: Ettl H., Gerloff J., Heynig H. and Mollenhauer D. (eds.), Süsswasser flora von Mitteleuropa, Band 2/1, Gustav Fischer Verlag, Stuttgart, New York, $876 \mathrm{p}$.

Krammer K. and Lange-Bertalot H., 1991. Bacillariophyceae. 4. Teil: Achnanthaceae, Kritische Ergänzungen zu Navicula (Lineolatae) und Gomphonema, Gesamtliteraturverzeichnis Teil 1-4. In: Ettl H., Gärtner G., Gerloff J., Heynig H. and Mollenhauer D. (eds.), Süsswasserflora von Mitteleuropa, Band 2/4, Gustav Fischer Verlag, Stuttgart, Jena, 437 p.

Krno I., Šporka F., Štefková E., Tirjaková E., Bitušík P., Bulánková E., Lukáš J., Illéšová D., Derka T., Tomajka J. and Černý J., 2006. Ecological study of a highmountain stream ecosystem (Hincov potok, High Tatra Mountains, Slovakia). Acta Soc. Zool. Bohem., 69, 299-316.

Kuczyńska-Kippen N., 2005. On body size and habitat selection in rotifers in a macrophyte-dominatedlake Budzyńskie, Poland. Aquat. Ecol., 39, 447-454.

Linhart J., Fiurášková M. and Uvira V., 2002. Moss- and mineral substrata-dwelling meiobenthos in two different loworder streams. Arch. Hydrobiol., 154, 543-560.

Linhartová Š., Uvíra V. and Linhart J., 2005. Stream meiobenthos and flow velocity - do mossy and mineral substrata differ? Verh. Int. Verein. Limnol., 29, 1069-1071.

Madaliński K., 1961. Moss dwelling rotifers of Tatra streams. Pol. Arch. Hydrobiol., 9, 243-263.

Malard F., Turquin M.J. and Magniez G., 1997. Filter effect of karstic spring ecotones on the population structure of the hypogean amphipod Niphargus virei. In: Gilbert J., Mathieu J. and Fournier F. (eds.), Groundwater/Surface Water Ecotones: Biological and Hydrological Interactions and Management Options, Cambridge University Press, Cambridge, $40-50$. 
Margaritora F., 1983. Cladoceri (Crustacea: Cladocera). Guide per il Reconoscimiento delle Specie Animali delle Acque Interne 22, Consiglio Nazionale delle Ricerche, Roma, 167 p.

Matoničkin Kepčija R., Habdija I., Primc-Habdija B. and Miliša M., 2006. Simuliid silk pads enhance tufa deposition. Arch. Hydrobiol., 166, 387-409.

Miliša M., Habdija I., Primc-Habdija B., Radanović I. and Matoničkin Kepčija R., 2006a. The role of flow velocity in the vertical distribution of particulate organic matter on moss-covered travertine barriers of the Plitvice Lakes (Croatia). Hydrobiologia, 553, 231-243.

Miliša M., Matoničkin Kepčija R., Radanović I., Ostojić A. and Habdija I., 2006b. The impact of aquatic macrophyte (Salix sp. and Cladium mariscus (L.) Pohl.) removal on habitat conditions and macroinvertebrates of tufa barriers (Plitvice Lakes, Croatia). Hydrobiologia, 573, 183197.

Miliša M., Živković V. and Habdija I., 2010. Destructive effect of quarry effluent on life in a mountain stream. Biologia, 65, $520-526$.

Moog O., 2002. Fauna Aquatica Austriaca. Edition 2002. Wasserwirtschaftskataster Bundesministerium für Landund Forstwirtschaft, Umwelt und Wasserwirtschaft, Wien, http://www.wassernet.at.

Nilsson A., 1996. Aquatic Insects of North Europe 1, Apollo Books, Stenstrup, 274 p.

Nilsson A., 1997. Aquatic Insects of North Europe 2, Apollo Books, Stenstrup, $440 \mathrm{p}$.

Nusch E.A., 1980. Comparison of different methods for chlorophyll and phaeopigment determination. Arch. Hydrobiol., 14, 14-36.

Ogden C.G. and Hedley R.H., 1980. An Atlas of Freshwater Testate Amoebae, BAS Printers Limited, Over Wallop, Hamoshire, 222 p.

Page F.C. and Siemensma F.J., 1991. Nackte Rhizopoda und Heliozoea, Gustav Fischer Verlag, Stuttgart, New York, 297 p.

Palmer M.A., 1990. Temporal and spatial dynamics of meiofauna within the hyporheic zone of Goose Creek, Virginia. J. $N$. Am. Benthol. Soc., 9, 17-25.

Patrick R. and Reimer C.W., 1966. The diatoms of the United States, exclusive of Alaska and Hawaii, Volume 1Fragilariaceae, Eunotiaceae, Achnanthaceae, Naviculaceae. Monogr. Acad. Nat. Sci. Phila., 13, 688.

Patrick R. and Reimer C.W., 1975. The diatoms of the United States, exclusive of Alaska and Hawaii, Volume 2, Part 1Entomoneidaceae, Cymbellaceae, Gomphonemaceae, Epithemaceae. Monogr. Acad. Nat. Sci. Phila., 13, 213.

Radoman P., 1983. Hydrobioidea: A Superfamily of Prosobranchia (Gastropoda). I. Systematics. Serbian Academy of Sciences and Arts, Monographs, Volume DXLVII, Department of Sciences, No 57, Sebian Academy of Sciences, Belgrade, $256 \mathrm{p}$.

Reiss J. and Schmid-Araya J.M., 2008. Existing in plenty: abundance, biomass and diversity of ciliates and meiofauna in small streams. Freshw. Biol., 53, 652-668.

Ricci C.N., 1987. Ecology of bdelloids: how to be successful. Hydrobiologia, 47, 117-127.

Rundle S.D., Robertson A.L. and Schmid-Araya J.M. (eds.), 2002. Freshwater Meiofauna: Biology and Ecology, Backhuys Publisher, Leiden, 369 p.
Sandlund O.T., 1982. The drift of zooplankton and microzoobenthos in the river Strandaelva, western Norway. Hydrobiologia, 94, 33-48.

Schmedtje U., 1995. Ökologische Grundlagen für die Beurteilung von Ausleitungsstrecken - Beziehungen zwischen der sohlnahen Strömung, dem Gewässerbett und dem Makrozoobenthos in Fließgewässern. Bayerisches Landesamt für Wasserwirtschaft (Hrsg.), Schriftenreihe, Heft 25, 158 p.

Sertić Perić M., Miliša M., Primc-Habdija B. and Habdija I., 2011. Seasonal and fine-scale spatial patterns of drift and seston in a tufa-depositing barrage hydrosystem. Fund. Appl. Limnol., 178, 131-145.

Sleight M.A., Baldock B.M. and Baker H., 1992. Protozoan communities in chalk streams. Hydrobiologia, 248, 53-64.

Smith F. and Brown A.V., 2006. Effects of flow on meiofauna colonization in artificial streams and reference sites within the Illinois River, Arkansas. Hydrobiologia, 571, 169-180.

Soininen J., 2004. Assessing the current related heterogeneity and diversity patterns of benthic diatom communities in a turbid and a clear water river. Aquat. Ecol., 38, 495-501.

Sørensen T., 1948. A method of establishing groups of equal amplitude in plant society based on similarity of species content. Kgl. Danske Videnskab. Selsk., 5, 1-34.

Špoljar M., Dražina T., Habdija I., Meseljević M. and Grčić Z., 2011. Contrasting zooplankton assemblages in two oxbow lakes with low transparencies and narrow emergent macrophyte belts (Krapina River, Croatia). Int. Rev. Hydrobiol., 96, 175-190.

Špoljar M., Habdija I. and Primc-Habdija B., 2007a. Transport of seston in the karstic hydrosystem of the Plitvice Lakes (Croatia). Hydrobiologia, 579, 199-209.

Špoljar M., Primc-Habdija B. and Habdija I., 2007b. The influence of the lotic and lentic stretches on the zooseston flux through the Plitvice Lakes (Croatia). Ann. Limnol. - Int. J. Lim., 43, 29-40.

Srdoč D., Horvatinčić N., Obelić B., Krajcar-Bronić I. and Sliepčević A., 1985. Calcite deposition processes in karst waters with special emphasis on the Plitvice lakes, Yugoslavia. Carsus Jugosl., 11, 101-204.

Stanley E.H., Short R.A., Harrison J.W., Hall R. and Wiedenfeld R.C., 1990. Variation in nutrient limitation of lotic and lentic algal communities in a Texas (USA) river. Hydrobiologia, 206, 61-71.

StatSoft, Inc., 2010. Statistica (Data Analysis Software System), v9.1, StatSoft Inc., Tulsa, OK, http://www.statsoft.com.

Stevenson R.J., Bothwell M.L., Lowe R.L. and Thorp J. H., 1996. Algal Ecology: Freshwater Benthic Ecosystem, Academic Press, San Diego, 753 p.

Stilinović B. and Plenković-Moraj A., 1995. Bacterial and phytoplanktonic research of Ponikve artificial lake on the island of Krk. Period. Biol., 97, 351-358.

Strayer D.L., May S.E., Nielsen P., Wollheim W. and Hausam S., 1997. Oxygen, organic matter, and sediment granulometry as controls on hyporheic animal communities. Arch. Hydrobiol., 140, 131-144.

Suren A.M., 1991. Bryophytes as invertebrate habitat in two New Zealand alpine streams. Freshw. Biol., 26, 399-418.

Suren A.M., 1992. Meiofaunal communities associated with bryophytes and gravels in shaded and unshaded alpine streams in New Zealand. N. Z. J. Mar. Freshwat. Res., 26, $115-125$. 
Suren A., 1993. Bryophytes and associated invertebrates in firstorder alpine streams of Arthur's Pass, New Zealand. N. Z. J. Mar. Freshwat. Res., 27, 479-494.

Wallace R.L. and Ricci C., 2002. Rotifera. In: Rundle S.D., Robertson A.L. and Schmid-Araya J.M. (eds.), Freshwater Meiofauna: Biology and Ecology, Backhuyus Publishers, Leiden, 15-45.

Waringer J. and Graf W., 1997. Atlas der Österreichischen Köcherfliegenlarven unter Einschluß angrenzender Gebiete, Facultas Universitätsverlag, Wien, 286 p.

Wilhartitz I.C., Kirschner A.K., Stadler H., Herndl G.J., Dietzel M., Latal C., Mach R.L. and Farnleitner A.H., 2009. Heterotrophic prokaryotic production in ultraoligotrophic alpine karst aquifers and ecological implications. FEMS Microbiol Ecol., 68, 287-99.

Zabelina M.M., Kiselev I.A., Proškina A.I. and Šešukova V.S., 1951. Opredelitelj presnovodnih vodoroslei SSSR. In: Diatomovie vodorosli, Gosudarstvenoe izdateljstvo Sovjetskaja nauka, Moskva, 619 p.

Zimmermann-Timm H., Holst H. and Kausch H., 2007. Spatial dynamics of rotifers in a large lowland river, the Elbe, Germany: how important are retentive shoreline habitats for the plankton community? Hydrobiologia, 593, 49-58.

Zwick P., 2004. Key to theWest Palaearctic genera of stoneflies (Plecoptera) in the larval stage. Limnologica, 34, 315-348. 